\title{
Analysis of Tourism Environment Carrying Capacity in Goa Kiskendo Forest Tourism BKPH Boja KPH Kendal
}

\author{
Eko Suwarno ${ }^{1}$, and Holi Bina Widjaya ${ }^{2}$ \\ ${ }^{1}$ Master Program of Environmental Science, School of Postgraduate Studies, Diponegoro University, Semarang - Indonesia \\ ${ }^{2}$ Department of Urban and Regional Planning, Faculty Engineering, Diponegoro University, Semarang - Indonesia
}

\begin{abstract}
The number of tourists who visit Goa Kiskendo Forest Tourism have been increased. By the increasing of tourists number will increase tourism activities so it will not be easy to manage it. It relates to realize the balance between tourism activities with environmental sustainability because with the increase will cause environmental damage. Therefore, to reduce the negative impacts, especially environmental biophysical conditions, it is necessary to conduct research on the carrying capacity analysis of the tourist environment in Goa Kiskendo Forest Tourism, which is linked to the maximum amount of visitors received in the area influenced by environmental biophysical aspects and management capacity. The method used refers to the Cifuentes formula (1992) which consists of Physical Carrying Capacity (PCC), Real Carrying Capacity (RCC) and Effective Carrying Capacity (ECC). Data collection was done by field observation / survey, literature study, questionnaire and limited interview. The carrying capacity analysis result of tourist environment in Goa Kiskendo Forest Tourism shows the PCC value is amount 3,930 visitors / day; RCC value is 276 visitors / day and ECC value is 184 visitors / day. This value when compared with the actual average number of current visitors is 37 visitors / day, is immobile far under the value of the effective carrying capacity analysis results. Founded on the effective carrying capacity value, the growth of Goa Kiskendo Forest Tourism can still be done by optimalization of the visitors number by $79.89 \%$ in accordance with the effective carrying capacity so the environmental conditions are stay awaked with the tourism activities in the location.
\end{abstract}

Keywords: carrying capacity; forest tourism; environmental biophysics; visitors.

\section{Introduction}

Goa Kiskendo Forest Tourism (GKFT) is one of forest tourism area through the Decree of the President Director of Perum Perhutani Number: 300 / Kpts / Dir / 2007 dated April 20, 2007, jo Decree Number 169 / Kpts / Dir / 2012 dated March 192012 and jo. Number 2397 / Kpts / Dir / 2014 dated February 28, 2014 on the Establishment of Forest Tourism Perum Perhutani with an area of 6.5 Ha. GKFT contributes to Perhutani KPH Kendal's revenue. From the tourism sector, KPH Kendal earned IDR 29.65 million in 2014 and increased to IDR 35.05 million in 2016. This indicates that GKFT has the potential to be a leading forest tourism. With the increase of tourists visiting, it is necessary to plan and manage the objects and tourist attraction. Planning, especially those in vulnerable locations, must pay attention to its environment limitation. In addition, environmental conditions need to be considered because with the disruption of environmental quality, the attraction will be disrupted or reduced [1]

The development of tourism in the future will certainly exploit the use of the forest. Although it is beneficial to increase the state's revenue, forest tourism development is not expected to cause natural damage. Incomplete tourism development can cause negative impacts such as environmental degradation, increased urbanization to tourist sites, stimulating crime and unrestrained informal socio-economic activities. Increased tourism activity are likely become a threat to biodiversity, due to its limited carrying capacity. Moreover, the increasing number of tourists encourages local people to take advantage from economic activities that have a negative impact on environmental sustainability [2].

The carrying capacity of normal tourism objects is the capability of an area to accept tourists, articulated in the amount of visitors per unit area per unit time [3].According to the Ministry of Culture and Tourism, aspects of carrying capacity in ecotourism areas that need to be considered are the number of tourists/year; length of tourist visit; how often ecologically "vulnerable" locations can be visited and others.Carrying capacity of the environment can verify the value of satisfaction and comfortness of visitors in enjoy tourism activities. This is because the carrying capacity is closely related to the number of tourists who come to visit these attractions.If the carrying capacity is exceeded then it can condense the console and satisfaction of tourists.

\footnotetext{
Corresponding author: ekosuwarno780@gmail.com
} 
Assessment of carrying capacity considering the environmental biophysical aspect is very important to do to find out the maximum threshold of the number of visitors located in the area at a time as "signs" for managers in planning for sustainable tourism development.It also needs to be done on GKFT considering its increasing tourist number.This increases physical stress along with other causes such as the use of transportation, the construction of tourist facilities, the pressure on natural resources, the destruction of wild habitats and pollution [4]. Those all comes from human activities.

Founded on the description, it is essential to review the maximum amount of visitors who can visit the GKFT so as not to cause negative impact on local environmental conditions. This study aim to calculate the carrying capacity of the tourist environment based on the environmental biophysical aspect as well as the management capacity in GKFT using the formula developed by Cifuentes (1992) with modifications from Fandeli and Muhammad [5].

\section{Methodology}

\subsection{Location and Time}

This study was conducted at GKFT which is administratively located in Trayu Village, Singorojo Subdistrict, Kendal Regency. It has altitude of 214 meters above sea level (asl). The estimate of carrying capacity is differentiated derived from the tourism management area that is: 1) public area, 6,388 ha; and 2) business area, 0.112 ha. This was done in May - June 2018.

\subsection{Data Collection}

Data collection include main data and secondary data. Main data were collected during express measurement techniques in the field, ie vegetation data to calculate correction factors (environmental biophysical parameters) and limited interviews and questionnaires to determine the value of visit rotation factor (Rf). While secondary data obtained through study of relevant literature.

\subsection{Data Analysis}

The analytical framework refers to the result procedure of carrying capacity urbanized by Cifuentes. This framework sets the maximum amount of visits founded on the physical, biological and managing conditions in the region, taking into account three core points: Physical Carrying Capacity (PCC), Real Carrying Capacity (RCC) and Effective Carrying Capacity [6].Some important elements to be considered include the tourist flows, the size of the area, the maximum amount of room obtainable for each of the tourists to progress without restraint and the time of visit [6].The formula (1) used modified Cifuentes method with Douglass (1975) by Fandeli \& Muhammad [5].

$$
P C C=A \times 1 / B \times R f
$$

(Formula (1)): where PCC is the maximum amount of visits that can be finished in one day; $A$ is the area used for tourism; B is the area needed by a tourist to travel while still obtaining satisfaction (picnic activity $B$ value is $65 \mathrm{~m}^{2}$ ); $\mathrm{Rf}$ is the rotation factor. Real carrying capacity refers to the Cifuentes formula in Zacarias et al (2011).

$$
R C C=P C C x C f_{1} x C f_{2} x \ldots \ldots x C f n
$$

(Formula (2)): RCC is the maximum amount of tourists who can visit a particular tourist area based on correction factors according to the local biophysical character. Cfn are correction factors of environmental biophysical parameters of a tourist area. It is calculated using the formula (3)[6].

$$
C f n=1-(M n / M t)
$$

(Formula (3)): $\mathrm{Cfn}$ is the n-correction factor associated with the nth component data; $\mathrm{Mn}$ is the real condition in the calculated fn variable; $\mathrm{Mt}$ is the maximum limit on the variable fn. The correction factor of the environmental biophysical aspect in the area of Goa Kiskendo Forest Tourism which is identified as a limiting factor on tourism activities, especially on tourist visits to the tourism area and the satisfaction and comfort of tourists moving freely.

Modifications of the formulas used by Siswantoro [7] and Sustri [8] was used in calculating these correction factors. Those are:

\subsubsection{Rainfall $\left(C f_{1}\right)$}

The rainy season affects tourism activities in GKFT. High rainfall intensity tend to decrease the number of tourist visits. Calculations are based on Rainfall Index over the last 10 years by comparing dry and wet months using equation [8]:

$$
\text { Index } \mathrm{CH}=\text { Wet moons: } \Sigma \text { Dry Moon }
$$

\subsubsection{Slope $\left(\mathrm{Cf}_{2}\right)$}

Flat or sloping ground will provide more comfort. The analysis was performed by using a scoring system on the criteria of the slope class on the segments of the area that were actively bypassed tourists [7] with reference to the classification of the slope class as in the Decree of the Minister of Agriculture No.837 / KPTS / UM / 11/1980 [9]. Points representing the topographic sloping conditions was measured its sope then calculated its average score.

\subsubsection{Soil Erosivity $\left(\mathrm{Cf}_{3}\right)$}

Land sensitivity greatly affects tourism activities. Tourist areas with high soil sensitivity have high erosion or landslide rates. The calculations were assessed in terms of sensitivity of soil erosion [7] by type of soil using the Erosion Level Index [9]. 


\subsubsection{Vegetation (Cf4)}

One of GKFT's tourism attractions is its biodiversity. Tourism activities can affect the presence and diversity of vegetation. The vegetation correction factor (Cf4) was calculated using the Simpson Diversity Index (IDS) $[7,8]$ :

$$
I D S=1-\lambda
$$

The effective carrying capacity is a product of a arrangement of real carrying capacity with the capacity of tourism locale management, as describe by the following formula:

$$
E C C=R C C \times M C
$$

(Formula (6)): ECC is the effective carrying capacity; RCC is the real carrying capacity; MC is the area management capacity.

The area management are calculated by comparing the amount of presented management officers (Rn) with the amount of management personnel needed (Rt). The formula [7] is:

$$
M C=R n / \text { Rt } \quad x \quad 100 \%
$$

\section{Results and Discussion}

The number of tourist in GKFT was increasing during the last four years (2014-2017) where the increase of visitor number reaches $171,60 \%$ (8,570 visitors) or $57,20 \%$ average increase per year (2,857 visitor/year).

Table 1. Number of GKFT Visitors in the period 2014-2017

\begin{tabular}{|c|r|}
\hline Year & \multicolumn{1}{|c|}{ Visitors } \\
\hline 2014 & 5.930 \\
\hline 2015 & 4.994 \\
\hline 2016 & 7.010 \\
\hline 2017 & 13.564 \\
\hline Total & 31.498 \\
\hline Average & 7.875 \\
\hline
\end{tabular}

Average visit duration divided into 3 categories ie 12 hours; 3-4 hours; 5-6 hours [10]. Based on questionnaires given to 90 respondents, $75.56 \%$ stayed for 1-2 hours; $22.22 \%$ stayed for 3-4 hours; and 2.22\% stayed for 5-6 hours. Every category is measured a single price, such as 3-4 hours is considered for 3.5 hours etc [10]; so the common trip duration is 2,03 hours based on the calculation below:

Average visit duration $=(1.5 \times 68)+(3.5 \times 20)+(5.5 \times 2) / 90$ $=2.03 \mathrm{hr}$.

Rotation factor $(\mathrm{Rf})=$ Tourist opening hours : average visit duration $=8: 2.03=3.93$

PCC for tourism activity using equation (1) to each management can be seen in Table 2 .
Table 2. Physical Carrying Capacity (PCC) of GKFT

\begin{tabular}{|c|c|c|c|c|}
\hline $\begin{array}{c}\text { Management } \\
\text { Area }\end{array}$ & $\begin{array}{c}\mathbf{A} \\
\left(\mathbf{m}^{\mathbf{2}}\right)\end{array}$ & $\begin{array}{c}\mathbf{B} \\
\left(\mathbf{m}^{\mathbf{2}}\right)\end{array}$ & $\begin{array}{c}\mathbf{R f} \\
(\mathbf{h o u r})\end{array}$ & $\begin{array}{c}\text { PCC Value } \\
(\text { Visitors/day })\end{array}$ \\
\hline Public Area & 63,880 & 65 & 3.93 & 3,862 \\
\hline $\begin{array}{c}\text { Business } \\
\text { Area }\end{array}$ & 1,120 & 65 & 3.93 & 68 \\
\hline Total & 65,000 & & & 3,930 \\
\hline
\end{tabular}

Based on table 2, the maximum number of visitors who can visit GKFT while still obtaining satisfaction is 3,930 visitors/day. B value using picnic-tourist activity category based on Douglass's (1975) [5] as of $65 \mathrm{~m}^{2}$.This PCC value still ignores biophysical factors, whereas one of the factors influencing the carrying capacity of the tourism environment is the biophysical environment factor that influences the strength or fragility of an ecosystem [3].Liu (1994) in Pitana \& Diarta [4] stated that the use of standard physical carrying capacity for tourist destinations is able to control the speed of development.

The actual average GKFT visitation is 37 visitors / day, still very far below PCC.The average visitor value is the average daily value within 1 year, not considering peak-season or off-season.In fact, the characteristics of visits to the GKFT follow this pattern. Peak-season is during the holiday season such as New Year Holiday (December and January), Independence Day (August) and school holidays/EidHolidays (May/June/July).

The PCC value is the basic value used to calculate the next parameter of carrying capacity [10]. The PCC value is worn to estimate the real carrying capacity (RCC) value constrained by the biophysical conditions of the narrow visitor area, so the last rate of the RCC is worse than the PCC value. The biophysical aspects of the correction factor were determined based on field observations and literature studies and limited interviews on tourism managers.

Various biophysical parameters are used by some researchers in calculating RCC, including rainfall $[6,10$, $11]$, sunlight $[6,10]$, erodibility $[6,10,11]$, accessibility $[10,11]$, biological factors and vegetation $[11,12]$, storm [10], wildlife interference [10], flooding [11], wind speed [6], temporary closure [6], climatology [12], soil conditions [12], water conditions [12], geological and geomorphological conditions [12].The observations in GKFT showed the biophysical aspects considered as limiting factors are rainfall $\left(\mathrm{Cf}_{1}\right)$, slopes $\left(\mathrm{Cf}_{2}\right)$, soil erosivity $\left(\mathrm{Cf}_{3}\right)$ and vegetation (Cf4). Calculation of the correction factor using formula (3) and the result is:

- Rainfall. Based on data from 2007-2016 GKFT has 86 months wet and 28 months dry. Based on formula (4), the result of rainfall index is 0.326 . It could be said that GKFT has wet climate. This rainfall index is then determined as Mrain with Mt value is 7 (the highest index value in Schmidt-Ferguson classification) so the rainfall correction factor $\left(\mathrm{Cf}_{1}\right)$ using formula (4) is 0.954 .

- Slopes. The slope of the public area is 60 and the business area is 30. This scores are then set as Mslope value with maximum value $(\mathrm{Mt})$ is 100 , so the correction 
factor $\left(\mathrm{Cf}_{2}\right)$ for each area is 0.40 for public area and 0.70 for business space.

-Soil Erosivitas. GKFT has latosol soil type with soil sensitivity index value of 30 (defined as Merosivity) with Mt value of 75 , so the correction factor $\left(\mathrm{Cf}_{3}\right)$ is 0.67 .

- Vegetation. Trees found in GKFT are Dalbergia latifolia, Tectona grandis, Delonix regia, Bauhinia purpurea, Acacia mangium, and Swietenia mahagoni. The vegetation diversity index is 0.728 set as Mvegetation with $\mathrm{Mt}$ is 1 so that the value of $\mathrm{Cf} 4$ is 0.272 .

The outcome of the overall adjustment part result can be seen in table 3 .

Table 3. Real Carrying Capacity (RCC) of GKFT

\begin{tabular}{|c|c|c|c|c|r|r|}
\hline \multirow{2}{*}{$\begin{array}{c}\text { Management } \\
\text { Area }\end{array}$} & \multicolumn{4}{|c|}{ Cfn Value } & $\begin{array}{c}\text { PCC Value } \\
\text { (visitors/day) }\end{array}$ & $\begin{array}{c}\text { RCC Value } \\
\text { (visitors/day) }\end{array}$ \\
\cline { 2 - 7 } & Cf1 & Cf2 & Cf3 & Cf4 & 268 \\
\hline Public Area & 0.954 & 0.40 & 0.67 & 0.272 & 3,862 & 8 \\
\hline $\begin{array}{c}\text { Business } \\
\text { Area }\end{array}$ & 0.954 & 0.70 & 0.67 & 0.272 & 68 & 276 \\
\hline \multicolumn{5}{|c|}{ Total } \\
\hline \multicolumn{7}{|c|}{} \\
\hline
\end{tabular}

The RCC value in table 3 shows the maximum number of visitors by considering environmental biophysical factors. The most biophysical condition that limits the number of visitors is vegetation correction factor. The GKFT vegetation diversity index value is at moderate level which means no dominant vegetation type and the diversity is quite stable.Diversity index can be used to assess human pressures [13]. If the diversity value of a nature tourism is low, it indicate that there has been pressure on environmental conditions in both habitat and species. If the carrying capacity of GKFT is exceeded, it can disturb the existing vegetation habitat condition in the tourism location. The next influential correction factor isthe slopes in public area. It categorized asmoderate steep - steep so it limits the number of visitors that this area can accommodate. The $10^{\circ}$ of slope or greater impacts the speed and health of the tourists [14]. The steep slopes will require more energy and result in fatigue thus affecting tourists in enjoying the nature [7].

The real carrying capacity of GKFT based on table 3 is 276 visitors/day or 99,486 per year.This value is still above the actual value $(7,875$ visitors/year) so the number of visitors can still be optimized up to $78.89 \%$. RCC value helped manager to maintain the balance between environmental conditions and number of visitors.This may provide a limitation to the use of tourism area prior to the decline in the quality of tourism resources or tourist experience [15].

Effective Carrying Capacity (ECC) is influenced by Capacity Management.KPH Kendal has 3 staff, but only 2 of them who effectively worked everyday. According to formula (7), the value of management capacity (MC) is $67 \%$. The ECC values of each area are determined based on formula (6) with the results as in Table 4.
Table 4. Effective Carrying Capacity (ECC) of GKFT

\begin{tabular}{|c|c|c|c|}
\hline $\begin{array}{c}\text { Management } \\
\text { Area }\end{array}$ & $\begin{array}{c}\text { RCC Value } \\
\text { (visitors/day) }\end{array}$ & $\begin{array}{c}\text { MC } \\
(\%)\end{array}$ & $\begin{array}{c}\text { ECC Value } \\
\text { (Visitors/day) }\end{array}$ \\
\hline Public Area & 268 & 0.67 & 179 \\
\hline $\begin{array}{l}\text { Business } \\
\text { Area }\end{array}$ & 8 & 0.67 & 5 \\
\hline Total & 276 & & 184 \\
\hline
\end{tabular}

The value of the effective carrying capacity associated with the organization capacity based on the calculation shows the number of 184 visitors / day or 5,527 visitors / month. Tran Nghi et al calculates the effective carrying capacity for ecotourism forest hiking actions in Phong Nha - Ke Bang National Park, Vietnam is 1450 visits per day [14]. Siswantoro (2012) in its calculation of the effective carrying capacity in wana wisata Grojogan Sewu gives results 1.002 visitors / day still below the actual amount of visits per day [7]. While Ortega et al (2011) in the calculation of the ECC obtained a value of 36 visits / day with a management capacity of $56 \%$ which indicates that the management of managers have limitations in the handling of tourists in large groups [11].

ECC value GKFT is 184 visitors/day or 5,527 visitors/month, still above the actual value so the tourist visits can still be optimized by $79.89 \%$. This means that GKFT staffs are still able to serve the number of visitors.To take a note, optimization of the number of visitors must be accompanied by the optimization of the personnel capacity up to $100 \%$. Management capacity consists of some variables such as legal basis, policy and rules, tools, workers, financing, infrastructure and facilities [6]. Optimization of the personnel capacity should be supported by management capacity based on these variables.This is to anticipate the decline in management competence especially throughout peakseason where the amount of visitors exceeds the carrying capacity.Based on the observations, there is a decrease in the quality of service during the peak-season which may be caused by the lack of management capacity from other aspects, such as the condition of infrastructure facilities and number of personnel [6].

\section{Conclusions}

Physical Carrying Capacity (PCC) of GKFT is 3,930 tourists/day; Real Carrying Capacity (RCC) is 276 visitors/day; and Effective Carrying Capacity (ECC) is 184 visitors/day. The overall value is still above the actual number (37 visitors/day). Therefore, the number of GKFT visitors can still be optimized up to $79.89 \%$ so that the balance of environmental conditions with tourism activities can still be maintained and sustainable. The development of Forest Tourism is one of them to absorb carbon from its vegetation, because its vegetation must be preserved. 


\section{References}

1. C. Fandeli, A. Suyanto, Kajian Daya Dukung Lingkungan Obyek dan Daya Tarik Wisata Taman Wisata Grojogan Sewu, Tawangmangu. Journal of Human and Environmental, 19 (7): 32 - 47 (1999)

2. F. Muhammad, Model Ekowisata Kawasan Hutan Mangrove Berbasis Daya Dukung Fisik Kawasan dan Resiliensi Ekologi (Kasus Ekowisata Mangrove Blanakan, Subang, Jawa Barat). Bogor Agricultural Institute. (2012)

3. O. Soemarwoto, Ekologi, Lingkungan Hidup dan Pembangunan .Edition 10th. Publisher Djambatan: Jakarta (2004)

4. I.G. Pitana, I.K.S. Diarta, Pengantar Ilmu Pariwisata. Publisher Andi: Yogyakarta (2009)

5. C. Fandeli, Muhammad, Prinsip-Prinsip Dasar Mengkonservasi Lanskap. Gadjah Mada University Press: Yogyakarta (2009)

6. D.A. Zacarias, A.T. Williams, A. Newton, Recreation Carrying Capacity Estimations To Support Beach Management At Praia De Faro, Portugal. Jounal of Applied Geography, 31: 10751081 (2011)

7. H. Siswantoro, Kajian Daya Dukung Lingkungan Wisata Alam Taman Wisata Alam Grojogan Sewu Kabupaten Karanganyar. (Thesis). Program Pasca Sarjana Universitas Diponegoro: Semarang (2012)

8. Sustri, Daya Dukung Wisata Alam di Taman Nasional Kepulauan Togean Sulawesi Tengah. (Thesis). Pasca Sarjana Ilmu Kehutanan Universitas Gadjah Mada: Yogyakarta (2009)
9. L. Mutu'ali, Daya Dukung Lingkungan untuk Perencanaan Pengembangan Wilayah. Yogyakarta: Badan Penerbit Fakultas Geografi UGM (2012)

10. M.S. Sayan, M. Atik, Recreation Carrying Capacity Estimates for Protected Areas: Study of Termessos National Park. Journal of Ecology 20, 78: 66 - 74 (2011)

11. J.L.C. Ortega, R.M.C. Dagostino, A.L.C. Magana, Estimating Carrying Capacity in A Natural ProtectedArea as a Conservation Strategy. Conference Proceedings' Impact Assessment and Responsible Development for Infrastructure, Business and Industry 31st Annual Meeting of the International Association for Impact Assessment 28 May- 4 June 2011. Centro de Convenciones, Puebla : Mexico (2011)

12. R. Hayati, Model Ambang Batas Fisik Dalam Perencanaan Kapasitas Area Wisata Berwawasan Konservasi di Kompleks Candi Gedong Songo Kabupaten Semarang. Journal of Geography, Vol. 7 No.1: 57-56 (2010)

13. I.A.S.L.P. Putri, M.K. Allo, Biodiversity Degradation of Rawa Aopa Watumohai National Park. Journal of Forest Research and Natural Conservation, Vol. VI No.2 : 169-194, (2009)

14. T. Nghi, N.T. Lan, N.D. Thai, D. Mai, D.X. Thanh, Tourism Carrying Capacity Assessment for PhongNha-Ke Bang anda Dong Hoi, Quan Binh Province. VNU Journal of Science, Earth Science 23 : 80-87 (2007)

15. D. Jovicic, A. Dragin, The Assessment of Carrying Capacity - A Crucial Tool for Managing Tourism Effects in Tourist Destinations. Journal of Turizam Volume 12: 4 -11(2008) 